\title{
MENELAAH DAMPAK PENERAPAN AKUNTANSI FORENSIK DALAM MENDETEKSI FRAUD PENGADAAN BARANG/JASA PADA SEKTOR PUBLIK
}

\author{
Suhartono $^{1}$, Raodahtul Jannah ${ }^{2}$ \\ Universitas Islam Negeri Alauddin Makassar \\ Jalan H.M. Yasin Limpo NO. 36, Samata-Gowa \\ *Email: suhartono@uin-alauddin.ac.id
}

\begin{abstract}
ABSTRAK
Permasalahan fraud telah terjadi di segala bidang, salah satunya yaitu fraud pengadaan barang/jasa. Fraud pengadaan barang/jasa identik dilakukan oleh organisasi sektor publik, baik dalam proses perencanaan, pelaksanaan, hingga penyelesaian akhir pengadaan. Akuntansi forensik merupakan solusi dalam mendeteksi terjadinya fraud. Tujuan penelitian ini untuk menelaah bagaimana dampak penerapan akuntansi forensik dalam mendeteksi fraud pengadaan barang/jasa pada sektor publik. Penelitian ini merupakan penelitian kualitatif dengan pendekatan fenomenologi. Hasil dari penelitian ini menunjukkan bahwa penerapan akuntansi forensik memiliki pengaruh signifikan terhadap pendeteksian fraud pengadaan barang dan jasa. Penerapan akuntansi forensik yang semakin baik akan berpengaruh positif dan dapat meningkatkan upaya keberhasilan dalam mendeteksi fraud pengadaan barang dan jasa. Selain itu, penerapan akuntansi forensik secara signifikan berpengaruh terhadap berkurangnya kasus-kasus fraud yang terjadi di sektor publik.
\end{abstract}

Kata Kunci: Akuntansi Forensik, Fraud Pengadaan Barang/Jasa, Sektor Publik

\begin{abstract}
Fraud problems have occurred in all fields, one of which is fraud in the procurement of goods / services. Identical goods / services procurement fraud is carried out by public sector organizations, both in the planning, implementation, and final procurement processes. Forensic accounting is a solution in detecting fraud. The purpose of this study is to examine how the impact of the application of forensic accounting in detecting fraud in procurement of goods / services in the public sector. This research is a qualitative research with a phenomenological approach. The results of this study indicate that the application of forensic accounting has a significant effect on the detection of fraud in the procurement of goods and services. The better application of forensic accounting will have a positive effect and can increase success efforts in detecting fraud in the procurement of goods and services. In addition, the application of forensic accounting has significantly reduced fraud cases that have occurred in the public sector.
\end{abstract}

Keywords: Forensic Accounting, Fraud of Goods / Services Procurement, Public Sector

\section{PENDAHULUAN}

Praktik fraud hampir terjadi di setiap daerah di Indonesia. Menurut catatan Komisi Pemberantasan Korupsi (KPK), sejak berdiri tahun 2002 hingga tahun 2019, telah berhasil membongkar 1.152 pelaku kasus fraud (korupsi) di Indonesia. Menjamurnya praktik fraud ini, sangat ironis melihat banyaknya strategi yang telah dirumuskan oleh lembaga pemerintahan dan lembaga sosial masyarakat dalam pemberantasan fraud. Hal ini menunjukkan bahwa strategi yang telah dirumuskan belum mampu untuk menuntaskan permasalahan fraud di Indonesia.

Permasalahan fraud telah terjadi di segala bidang, salah satunya yaitu fraud pengadaan barang/jasa. Fraud pengadaan barang/jasa identik dilakukan oleh organisasi 
sektor publik, baik dalam proses perencanaan, pelaksanaan, hingga penyelesaian akhir pengadaan (Artantri et al., 2016). Pengadaan barang/jasa merupakan aktivitas yang sangat berpotensi terjadinya fraud, melihat jumlah anggaran yang terus bertambah setiap tahunnya (Wiharti \& Novita, 2020). Menurut Wakil Komisi Pemberantasan Korupsi (KPK) Nawawi Pomolongan (2020), kasus yang ditangani KPK sampai saat ini masih tercatat 70 persen kasus mengenai pengadaan barang dan jasa. Melihat banyaknya kasus fraud pengadaan barang/jasa, maka memberikan gambaran buruknya kualitas barang/jasa yang dihasilkan oleh organisasi sektor publik.

Fenomena ini harus disikapi dengan baik karena fraud terus menerus terjadi dan berulang kali. Diperlukan adanya suatu cara untuk mendeteksi terjadinya fraud pada organisai sektor publik. Akuntansi forensik merupakan solusi dalam mendeteksi terjadinya fraud (Wiralestari, 2016). Akuntansi forensik berperan dalam menghitung besarnya kerugian yang timbul karena perbuatan melawan hukum, seperti fraud pengadaan barang/jasa (Jenitra, 2018). Selain itu, akuntan forensik dalam menjalankan tugasnya akan mencari bukti kuat dari perbuatan melawan hukum, sehingga dapat dipertanggungjawabkan di pengadilan bilamana diperlukan.

Akuntansi forensik di Indonesia sebenarnya bukan hal baru. Akuntansi forensik di Indonesia mulai dikenal setelah keberhasilan Pricewaterhouse Coopers (PwC) dalam membongkar kasus Bank Bali. PwC dalam kasus Bank Bali mampu menunjukkan arus dana yang rumit berbentuk seperti diagram cahaya yang mencuat dari matahari (sunburst), kemudian PwC meringkasnya menjadi arus dana dari orang-orang yang terlibat dalam kasus ini. Melihat keberhasilan ini, akuntansi forensik akan sangat membantu dalam mengatasi permasalahan fraud di Indonesia. Akan tetapi, Indonesia belum memiliki standar khusus yang mengatur tentang penggunaan akuntansi forensik, sehingga minat akuntan untuk mendalami ilmu ini masih minim (Jenitra, 2018).

Terlepas dari minimnya akuntan yang mendalami ilmu akuntansi forensik. Penelitian mengenai akuntansi forensik dalam mendeteksi fraud pengadaan barang/jasa telah banyak dilakukan. Penelitian yang telah dilakukan, yaitu diantaranya Larasati et al. (2017), Wiharti \& Novita (2020), Artantri et al. (2016), Ramadhan \& Arifin (2019), dan Putri (2017). Dengan dilakukannya praktik akuntansi forensik di Indonesia, belum dapat diukur apakah penerapan akuntansi forensik telah membantu dalam mendeteksi fraud pengadaan barang/jasa pada sektor publik. Oleh karena itu, penelitian ini akan menelaah 
bagaimana dampak penerapan akuntansi forensik dalam mendeteksi fraud pengadaan barang/jasa pada sektor publik.

\section{TINJAUAN PUSTAKA}

\section{Organisasi Sektor Publik}

Secara garis besar, organisasi adalah sekelompok orang yang secara bersamasama ingin mencapai sebuah tujuan. Sedangkan sektor publik sendiri sering diartikan sebagai suatu entitas yang aktivitasnya berhubungan dengan penyediaan barang dan jasa dalam memenuhi kebutuhan dan hak publik. Jadi, organisasi sektor publik merupakan sebuah organisasi yang berorientasi pada kepentingan publik. Karena orientasi dari organisasi ini mengarah pada kepentingan publik, maka tujuan akhir dari orientasi ini bukanlah pada pencapaian laba. Dalam praktiknya, organisasi sektor publik adalah organisasi yang menggunakan dana masyarakat, sehingga perlu untuk melakukan pertanggungjawaban kepada masyarakat.

\section{Pengadaan Barang dan Jasa}

Ketersediaan barang/jasa yang berkualitas dalam penyelenggaraan pemerintahan akan sangat berpengaruh dalam peningkatan pelayanan publik. Upaya dalam memperoleh barang atau jasa yang berkualitas tersebut harus dilakukan melalui persaingan yang sehat, terbuka dan adil sehingga dapat tercapai efisiensi dan efektifitas pengadaan barang dan jasa yang maksimal (Putri, 2017). Secara umum, menurut Peraturan Presiden Republik Indonesia Nomor 16 Tahun 2018 tentang Pengadaan Barang/Jasa Pemerintah, pengertian pengadaan barang dan jasa adalah kegiatan pengadaan Barang/ Jasa oleh Kementerian/ Lembaga/ Perangkat Daerah yang dibiayai oleh APBN/ APBD yang prosesnya sejak identifikasi kebutuhan, sampai dengan serah terima hasil pekerjaan. Pengadaan Barang/Jasa dalam Peraturan Presiden ini yaitu meliputi: barang, pekerjaan konstruksi, jasa konsultansi; dan jasa lainnya. Sementara metode dalam pengadaan barang dan jasa dapat dilaksanakan dengan pelelangan umum, pelelangan terbatas, pemilihan langsung, penunjukan langsung maupun swakelola.

Pihak- pihak yang terlibat dalam Pengadaan Barang dan Jasa, yaitu
a. Pengguna Anggaran (PA);
b. Kuasa Pengguna Anggaran (KPA);
c. Pejabat Pembuat Komitmen (PPK);
d. Pejabat Pengadaan; 
e. Pokja Pemilihan;

f. Agen Pengadaan

g. Panitia/ Pejabat Penerima Hasil Pekerjaan (PPHP);

h. Penyelenggara Swakelola; dan

i. Penyedia

Pengadaan Barang/Jasa bertujuan untuk:

a. Menghasilkan Barang/Jasa yang tepat dari setiap uang yang dibelanjakan, diukur dari aspek kualitas, jumlah, waktu, biaya, lokasi, dan penyedia;

b. Meningkatkan penggunaan produk dalam negeri;

c. Meningkatkan peran serta Usaha Mikro, Usaha Kecil, dan Usaha Menengah;

d. Meningkatkan peran pelaku usaha nasional;

e. Mendukung pelaksanaan penelitian dan pemanfaatan barang/jasa hasil penelitian;

f. Meningkatkan keikutsertaan industri kreatif;

g. Mendorong pemerataan ekonomi; dan

h. Mendorong Pengadaan Berkelanjutan.

\section{Fraud}

Fraud atau dalam bahasa Indonesia lebih dikenal dengan kecurangan merupakan sebuah objek utama yang diperangi dalam akuntansi forensik dan dibuktikan dalam audit investigatif. Kecurangan adalah suatu pengertian umum yang mencakup beragam cara yang dapat digunakan oleh kecerdikan manusia, yang digunakan seseorang untuk mendapatkan keuntungan dari orang lain melalui perbuatan yang tidak benar. Kecurangan adalah penipuan yang disengaja, umumnya dalam bentuk kebohongan, penjiplakan dan pencurian. Kecurangan dilakukan untuk memperoleh keuntungan berupa uang dan kekayaan, atau untuk menghindari pembayaran atau kerugian jasa, menghindari pajak serta mengamankan kepentingan pribadi atau suatu usaha tertentu (Sayyid, 2014). Kecurangan semacam ini menunjukkan adanya keinginan yang disengaja, dan tidak termasuk ketidaktahuan.

Selain pengertian di atas, berikut beberapa macam pengertian fraud atau kecurangan lainnya, yaitu:

a. Menurut Tommie W. Singleton dan Aaron J, kecurangan adalah perbuatan mencakup akal muslihat, kelicikan, dan tidak jujur dan cara-cara yang tidak layak/wajar untuk menipu orang lain untuk keuntungan diri sendiri, sehingga menimbulkan kerugian bagi pihak lain. 
b. Menurut G. Jack Bologna, Robert J. Lindquist dan Joseph T. Wells, Kecurangan adalah penipuan kriminal yang bermaksud memberi manfaat keuangan kepada si penipu.

Wiralestari (2016) menyatakan bahwa fraud dapat sedini mungkin terdeteksi jika seorang manajemen atau internal auditor jeli melihat tanda-tanda fraud. Tanda- tanda fraud tersebut diantaranya adalah sebagai berikut:

1. Terdapat perbedaan angka laporan keuangan yang mencolok dengan tahun sebelumnya.

2. Tidak ada pembagian tugas dan tanggung jawab yang jelas.

3. Seseorang menangani hampir semua transaksi yang penting.

4. Transaksi yang tidak didukung oleh bukti yang memadai.

5. Perkembangan perusahaan yang sulit.

Fraud terdiri dari tiga jenis penyimpangan, menurut Association of Certified Fraud Examiners (ACFE) dalam Artantri et al. (2016) membagi fraud (fraud) dalam 3 (tiga) jenis atau tipologi berdasarkan perbuatan yaitu:

1. Penyimpangan atas aset (Asset Misappropriation) Asset misappropriation meliputi penyalahgunaan/pencurian aset atau harta perusahaan atau pihak lain. Ini merupakan bentuk fraud yang paling mudah dideteksi karena sifatnya yang tangible atau dapat diukur/dihitung (defined value).

2. Pernyataan palsu atau salah pernyataan (Fraudulent Statement) Fraudulent statement meliputi tindakan yang dilakukan oleh pejabat atau eksekutif suatu perusahaan atau instansi pemerintah untuk menutupi kondisi keuangan yang sebenarnya dengan melakukan rekayasa keuangan (financial engineering) dalam penyajian laporan keuangannya untuk memperoleh keuntungan atau mungkin dapat dianalogikan dengan istilah window dressing

3. Korupsi (Corruption) Fraud jenis ini sering kali tidak dapat dideteksi karena para pihak yang bekerja sama menikmati keuntungan (simbiosis mutualisme). Termasuk di dalamnya adalah penyalahgunaan wewenang/konflik kepentingan (Conflict Of Interest), penyuapan (Bribery), penerimaan yang tidak sah/illegal (Illegal Gratuities), dan pemerasan secara ekonomi (Economic Extortion).

Menurut Shodiq et al. (2013) dalam penelitiannya, ada empat faktor yang menjadi penyebab seseorang melakukan kecurangan, dikenal dengan teori GONE (Greed, Opportunity, Need, and Exposure), yaitu: 
a. greed (keserakahan), berkaitan dengan adanya perilaku serakah yang secara potensial ada di dalam diri setiap orang.

b. opportunity (kesempatan), berkaitan dengan keadaan organisasi atau instansi masyarakat yang sedemikian rupa sehingga terbuka kesempatan bagi seseorang untuk melakukan fraud terhadapnya.

c. needs (kebutuhan), berkaitan dengan faktor-faktor yang dibutuhkan oleh individu untuk menunjang hidupnya yang menurutnya wajar.

d. exposure (pengungkapan), berkaitan dengan tindakan atau konsekuensi yang akan dihadapi oleh pelaku fraud apabila pelaku ditemukan melakukan fraud.

Sedangkan menurut Anggraini et al. (2019) ada tiga sudut pemicu seseorang melakukan kecurangan, tiga sudut tersebut dapat dijelaskan dalam bentuk fraud triangle atau segitiga fraud, yaitu:

1. Tekanan (Unshareable pressure/ incentive). Merupakan motivasi seseorang untuk melakukan fraud. Motivasi melakukan fraud, antara lain motivasi ekonomi, alasan emosional (iri/cemburu, balas dendam, kekuasaan, gengsi), nilai (values) dan apa pula karena dorongan keserakahan.

2. Adanya kesempatan / peluang (Perceived Opportunity). Yaitu kondisi atau situasi yang memungkinkan seseorang melakukan atau menutupi tindakan tidak jujur. Biasanya hal ini dapat terjadi karena adanya internal control perusahaan yang lemah kurangnya pengawasan, dan/atau penyalahgunaan wewenang.

3. Rasionalisasi (Rationalization). Merupakan elemen penting dalam terjadinya fraud, dimana pelaku mencari pembenaran sebelum melakukan kejahatan, bukan sesudah melakukan tindakan tersebut. Rasionalisasi diperlukan agar si pelaku dapat mencerna perilakunya yang illegal untuk tetap mempertahankan jati dirinya sebagai orang yang dipercaya, tetapi setelah kejahatan dilakukan, rasionalisasi ini ditinggalkan karena sudah tidak dibutuhkan lagi. Rasionalisasi atau sikap (attitude), yang paling banyak digunakan adalah hanya meminjam (borrowing) asset yang dicuri dan alasan bahwa tindakannya untuk membahagiakan orangorang yang dicintainya.

Berdasarkan data rekapitulasi IHPS BPK I Tahun 2014, fraud dalam pengadaan barang dan jasa di Indonesia, terbagi menjadi tiga jenis, yaitu (1) yang menimbulkan potensi kerugian negara; (2) yang menimbulkan kekurangan penerimaan; dan (3) yang menimbulkan ketidakefektifan. Lebih lanjut, fraud dalam pengadaan barang dan jasa 
berpotensi dapat terjadi yaitu pada tahapan perencanaan pengadaan, pelaksanaan lelang maupun pelaksanaan pekerjaan (Putri, 2017).

Larasati et al. (2017) menyatakan bahwa pencegahan fraud dalam hal pengadaan barang publik, terdiri dari:

a. Memperkuat kerangka hukum.

b. Prosedur transparan.

c. Membuka dokumen tender.

d. Evaluasi penawaran.

e. Melimpahkan wewenang.

f. Pemeriksaan dan audit independen.

\section{Akuntansi Forensik}

Lidyah (2016) mengemukakan bahwa awalnya di Amerika Serikat akuntansi forensik digunakan untuk menentukan pembagian warisan atau mengungkap motif pembunuhan. Istilah akuntansi forensik tersebut bermula dari penerapan akuntansi untuk menyelesaikan atau memecahkan persoalan hukum. Di Amerika, profesi yang bergerak di bidang akuntansi forensik disebut auditor forensic atau pemeriksa fraud bersertifikasi Certified Fraud Examiners (CFE) yang bergabung dalam Association of Certified Fraud Examiners (ACFE).

Akuntansi forensik adalah suatu aplikasi keterampilan investigasi dan analitik yang memiliki tujuan untuk menyelesaikan masalah-masalah keuangan melalui caracara yang sesuai dengan standar yang ditetapkan oleh pengadilan dan hukum (Larasati et al., 2017). Secara sederhana akuntansi forensik dapat dikatakan sebagai akuntansi yang akurat dalam tujuan hukum, yang tahan uji dalam kancah perseteruan selama proses pengadilan, dan dalam proses peninjauan yudisial ataupun tinjauan administratif (Wiralestari, 2016). Akuntan forensik memiliki tugas untuk memberikan pendapat hukum dalam pengadilan (litigation). Disamping itu, akuntan forensik juga memiliki peran akuntan forensik dalam bidang hukum di luar pengadilan (non litigation) misalnya dalam membantu merumuskan alternatif penyelesaian perkara dalam sengketa, perumusan perhitungan ganti rugi dan upaya dalam menghitung dampak pemutusan/ pelanggaran kontrak (Lidyah, 2016).

Akuntansi forensik dibagi ke dalam dua bagian: 
1. Jasa penyelidikan (investigative services) mengarahkan pemeriksa penipuan atau auditor penipuan, yang mana mereka menguasai pengetahuan tentang akuntansi mendeteksi, mencegah, dan mengendalikan penipuan, dan misinterpretasi.

2. Jasa litigasi (litigation services) merepresentasikan kesaksian dari seorang pemeriksa penipuan dan jasa-jasa akuntansi forensik yang ditawarkan untuk memecahkan isu-isu valuasi, seperti yang dialami dalam kasus perceraian. Sehingga, tim audit harus menjalani pelatihan dan diberitahu tentang pentingnya prosedur akuntansi forensik di dalam praktek audit dan kebutuhan akan adanya spesialis forensik untuk membantu memecahkan masalah.

Akuntansi forensik meliputi investigasi kecurangan dan menginvestigasi pembukuan keuangan maupun catatan yang berkaitan dengan tindak pidana korupsi. Berbeda dengan auditor yang memberikan opini terhadap suatu laporan keuangan, Akuntansi forensik lebih berfokus pada suatu dugaan atau sebuah peristiwa tertentu. Oleh karena itu, akuntansi forensik harus memiliki peran yang efektif dalam menyelidiki dan membuktikan adanya tindak pidana korupsi (Claudia, 2018). Tuanakotta, 2010 dalam (Lidyah, 2016) mengatakan bahwa kualitas yang harus dimiliki oleh seorang akuntan forensik adalah:

a. Kreatif: kemampuan untuk melihat sesuatu yang orang lain menganggap situasi bisnis normal dan mempertimbangkan interpretasi lain, yakni bahwa itu tidak perlu merupakan situasi bisnis yang normal.

b. Rasa ingin tahu: keinginan untuk menemukan apa yang sesungguhnya terjadi dalam rangkaian peristiwa dan situasi.

c. Tidak menyerah: kemampuan untuk maju terus pantang mundur walaupun fakta (seolah-olah) tidak mendukung, dan ketika dokumen atau informasi sulit diperoleh.

d. Akal sehat: kemampuan untuk mempertahankan perspektif dunia nyata. Ada yang menyebutnya perspektif anak jalanan yang mengerti betul kerasnya kehidupan.

e. Business sense: kemampuan untuk memahami bagaimana bisnis sesungguhnya berjalan, dan bukan sekedar memahami bagaimana transaksi dicatat

f. Percaya diri: kemampuan untuk mempercayai diri dan temuan kita sehingga kita dapat bertahan di bawah cross examination (pertanyaan silang dari jaksa penuntut umum dan pembela). 
Lidyah (2016) mengemukakan bahwa di sektor publik maupun privat, akuntansi forensik berurusan dengan kerugian, di sektor publik berurusan dengan kerugian bagi negara dan keuangan Negara, sedangkan di sektor privat, berurusan dengan kerugian karena terjadi cidera janji dalam suatu perikatan. Kerugian merupakan titik pertama dalam segitiga akuntansi forensik. Titik kedua adalah tindakan/perbuatan melawan hukum yang dapat menimbulkan tuntutan akibat terjadi kerugian. Titik ketiga menunjukkan adanya keterkaitan antara kerugian dengan perbuatan melawan hukum. Berikut ini segitiga akuntansi forensik yang menjelaskan hubungan kausalitas antara kerugian dengan perbuatan melawan hukum.

\section{Segitiga Akuntansi Forensik}

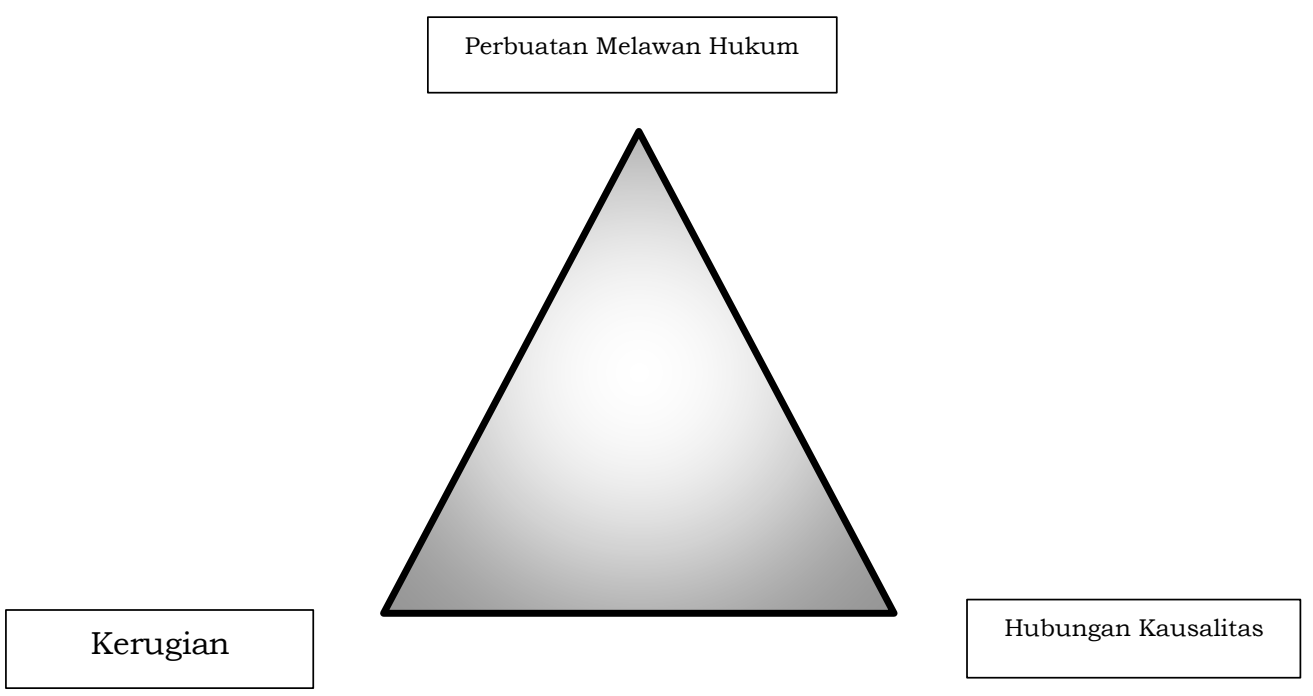

Perbuatan melawan hukum dan hubungan kausalitas adalah ranah para ahli dan praktisi hukum, sedangkan perhitungan besarnya kerugian yang timbul karena perbuatan melawan hukum adalah ranah akuntan forensik. Akuntan forensik membantu para ahli dan praktisi hukum dalam mengumpulkan bukti dan barang bukti untuk menentukan hubungan kausalitas tersebut. Segitiga akuntansi forensik, selain menjelaskan hubungan kausalitas antara kerugian dengan perbuatan melawan hukum, juga menjelaskan hubungan antara ilmu akuntansi, hukum, dan auditing.

\section{METODE PENELITIAN}

Penelitian ini merupakan jenis penelitian kualitatif dengan pendekatan fenomenologi. Penelitian kualitatif merupakan penelitian yang secara mendalam mengkaji suatu objek demi mendapatkan informasi dan data-data yang terperinci (Sugiyono, 2014). Sedangkan pendekatan fenomenologis adalah penelitian yang berusaha untuk memahami makna suatu 
peristiwa serta interaksi pada orang-orang biasa dalam situasi tertentu. Pendekatan ini bertujuan untuk memahami respon atas keberadaan dari manusia atau masyarakat serta pengalaman yang dipahami dalam melakukan interaksi (Afiyanti, 2008). Metode yang digunakan dalam pendekatan fenomologi terdiri atas tahap intuisi, analisis serta deskripsi dan yang hasil keseluruhannya berupa deskripsi fenomenologis. Oleh karena itu, hasil dari penelitian kualitatif mampu mengungkapkan fenomena-fenomena pada suatu subjek yang diteliti secara mendalam.

Penelitian ini mengumpulkan data-data penelitian dengan menggunakan metode studi literature. Studi literatur sendiri merupakan metode penelitian yang berusaha mensintesa berbagai hasil penelitian sebelumnya untuk kemudian dikaji dan dijadikan bahan pembuatan hasil dan kesimpulan penelitian untuk menjamin keabsahan data penelitian digunakan triangulasi sumber data dan teori untuk analisa data sendiri dilakukan dalam tiga tahap yaitu dengan pengumpulan literatur penelitian, transkip data, dan penyimpulan akhir (Afiyanti, 2008).

\section{HASIL DAN PEMBAHASAN}

\section{Dampak Penerapan Akuntansi Forensik Dalam Mencegah Fraud Terhadap Pengadaan Barang/Jasa}

Pengadaan barang dan jasa merupakan proses kesinambungan pertukaran yang menggunakan sumber daya keuangan perusahaan untuk dijadikan alat produksi (capital expenditures), yang sangat berpotensi sekali terjadi penyimpangan dan kecurangan. Pengadaan barang dan jasa publik merupakan aktivitas yang sensitif melihat dari jumlah anggaran yang sangat signifikan dan terus bertambah anggaran setiap tahunnya (Wiharti \& Novita, 2020). Berdasarkan kategori penanganan kasus tindak pidana korupsi berdasarkan jenis perkara sepanjang tahun 2004 hingga tahun 2019 terdiri dari 661 perkara penyuapan, 205 perkara pengadaan barang dan jasa, 48 perkara penyalahgunaan anggaran, 34 perkara tindak pidana pencucian uang, 26 perkara pungutan, 23 perkara perizinan, dan 10 perkara merintangi proses KPK (Anti-Corruption Clearing House, 2019). Sehubungan dengan risiko yang sangat besar dalam proses pengadaan barang dan jasa ini, mengingat dalam proses pengadaan barang/jasa sangat memerlukan pengawasan dan pemeriksaan yang tepat, karena terdapat beberapa risiko dalam pengadaan barang/jasa yaitu antara lain: kualitas pengendalian intern, besarnya nilai pengadaan barang dan jasa, tingginya tingkat risiko kegagalan pemanfaatan atas pengadaan barang dan jasa, serta kompleksitas kegiatan 
pengadaan barang dan jasa, yang kemungkinan besar terjadi fraud pada kegiatan pengadaan barang dan jasa dan diperkirakan memiliki pengaruh yang besar pada pencapaian tujuan pengadaan barang dan jasa. Maka dari itu perlu adanya upaya dan strategi yang tepat untuk mencegah, mendeteksi dan mengungkapkan fraud yang sangat mungkin sekali terjadi pada pengadaan barang dan jasa.

Tindakan fraud yang hampir sering dijumpai pada setiap tahap dalam proses pengadaan barang/jasa mulai dari perencanaan, pembentukan panitia pengadaan, proses pengadaan, penyusunan kontrak, sampai dengan pelaksanaan kontrak (Modul Pelatihan Pengadaan Barang/Jasa Pemerintah., 2010). Mengingat ancaman nyata dalam fraud pengadaan barang dan jasa yang dapat menyebabkan buruknya kualitas barang/jasa yang dihasilkan sehingga tidak dapat melayani kepentingan publik secara efektif dan efisien. Dalam kondisi ini penerapan akuntansi forensik dan audit investigasi sangat dibutuhkan, akuntansi forensik merupakan penerapan disiplin akuntansi dalam arti luas, termasuk auditing pada masalah hukum untuk penyelesaian hukum di dalam atau di luar pengadilan (Tuanakotta, 2016), sedangkan keterampilan audit Investigasi dibutuhkan untuk mengumpulkan bukti, menganalisis bukti, mengevaluasi bukti, menafsirkan dan mengkomunikasikan hasil temuan kemungkinan terjadinya (ada atau tidaknya) pelanggaran/perbuatan melawan hukum.

Sesuai dengan penelitian yang dilakukan oleh (Fauzan et al., 2014) yang menyimpulkan bahwa akuntansi forensik serta audit investigasi berpengaruh sangat baik secara parsial maupun simultan terhadap pengungkapan fraud. Serta sejalan dengan penelitian lainnya yang dilakukan oleh (Rizki et al., 2017) menyatakan bahwa akuntansi forensik dan audit investigasi masing-masing memiliki efek positif yang signifikan pada deteksi kejahatan kerah putih (White Collar Crime). Maka dari itu penerapan Akuntansi forensik dan Audit Investigasi sangat dibutuhkan dalam upaya mendeteksi fraud karena perkembangan fraud yang semakin pesat dari hari ke hari. Hal ini dapat membantu untuk mengurangi kasus fraud seperti korupsi yang sering terjadi di Lingkungan Pemerintahan, serta dapat mengembalikan dan meningkatkan kepercayaan publik kepada pemerintahan (Wiharti \& Novita, 2020).

\section{Penerapan Akuntansi Forensik Berpengaruh Dalam Mendeteksi Fraud Pengadaan Barang/Jasa}

Dengan melakukan penerapan akuntansi forensik dilengkapi dengan pengetahuan dan keterampilan audit investigatif, seperti taktik pengawasan, wawancara, dan keahlian 
interogasi, membantu akuntan forensik memiliki keterampilan lain di luar keterampilan yang berkaitan dengan audit dan mampu memadukan dengan aspek keuangan dan hukum. Kemampuan ini akan membantu akuntan forensic dalam melakukan pencarian barang bukti dan menjadi saksi saat persidangan. Adapun hasil penelitian sebelumnya yang menjadi dasar penelitian ini ialah penelitian yang dilakukan oleh (Ardiansyah et al., 2016) mengungkapkan bahwa Audit investigasi berpengaruh signifikan terhadap pendeteksian fraud.

Hal ini didukung oleh hasil penelitian sebelumnya yang dilakukan oleh (Okoye \& Gbegi, 2013) yang menyatakan bahwa Penerapan akuntansi forensik secara signifikan berpengaruh terhadap berkurangnya kasus-kasus fraud yang terjadi di sektor publik. Penerapan Akuntansi forensik dapat membantu lebih baik dalam upaya pencegahan dan pendeteksian fraud di organisasi sektor publik. Selain itu penelitian yang dilakukan (Wawolangi, 2014) hasil penelitiannya juga menunjukkan bahwa penerapan akuntansi forensik sangat dibutuhkan dengan upaya utama mendeteksi fraud, dan masyarakat sudah mulai merasakan pentingnya penerapan akuntansi forensik demi kelangsungan dan pengembangan ekonomi negara Indonesia. Akuntan forensik dapat mendeteksi penyebab terjadinya kecurangan. Terdapat tiga kategori utama kecurangan yaitu korupsi, asset misappropriation, dan kecurangan laporan keuangan. Ketiga kategori kecurangan ini menimbulkan kerugian bagi negara dan keuangan negara (Wiharti \& Novita, 2020).

\section{Pengaruh Akuntansi Forensik Terhadap Kecurangan Pada Sektor Publik}

Hasil uji Kruskal Wallis menunjukkan menunjukkan bahwa Akuntansi Forensik dapat digunakan untuk mengurangi kecurangan pada sektor publik. Hal ini dikarenakan di Indonesia, memang penggunaan akuntansi forensik lebih dibutuhkan pada sektor publik dibandingkan dengan sektor privat karena jumlah perkara yang lebih banyak di sektor publik. Kecurangan akuntansi yang biasanya dilakukan yaitu dalam bentuk korupsi dana Anggaran Pendapatan dan Belanja Negara/Daerah (APBN/APBD). Peran akuntansi forensik dalam penyidikan tindak pidana korupsi dilaksanakan untuk membantu seorang penyidik tindak pidana korupsi salah satunya yaitu menghitung kerugian keuangan negara. Penghitungan kerugian keuangan negara merupakan suatu proses untuk memperoleh kesimpulan kerugian keuangan negara yang dimuat dalam klausul dakwaan jaksa penuntut umum tindak pidana korupsi.

Akuntansi forensik dapat menghitung jumlah kerugian negara dengan melakukan teknik audit investigatif, wawancara mendalam dan melakukan penelusuran terhadap jejak- 
jejak arus uang. Dengan adanya penelusuran bukti-bukti yang ada maka dapat disimpulkan berapa besarnya jumlah kerugian keuangan negara yang terjadi serta modus operandi yang dilakukan tersangka tindak pidana korupsi. Jumlah kerugian negara ini nantinya akan dijadikan dasar berapa jumlah yang harus dikembalikan kepada negara oleh terpidana korupsi atas perbuatan korupsi yang telah dilakukannya. Dalam hal ini akuntansi forensik memiliki peran penting agar korupsi yang terjadi pada sektor publik dapat ditindaklanjuti secara tegas dan diharapkan dapat mengurangi segala bentuk kecurangan yang terjadi pada sektor publik. Dimana hal ini sesuai dengan pernyataan Okoye (2013) dan Gbegi (2014) yang menyatakan bahwa akuntansi forensik dapat mengurangi kecurangan pada sektor publik (Jenitra, 2018).

\section{PENUTUP}

Berdasarkan pembahasan pada bagian sebelumnya, maka dapat ditarik kesimpulan bahwa penerapan akuntansi forensik memiliki pengaruh signifikan terhadap pendeteksian fraud pengadaan barang dan jasa. Penerapan akuntansi forensik yang semakin baik akan berpengaruh positif dan dapat meningkatkan upaya keberhasilan dalam mendeteksi fraud pengadaan barang dan jasa. Selain itu, penerapan akuntansi forensik secara signifikan berpengaruh terhadap berkurangnya kasus-kasus fraud yang terjadi di sektor publik. Penerapan akuntansi forensik dapat membantu lebih baik dalam upaya pencegahan dan pendeteksian fraud di organisasi sektor publik. Akuntansi forensik sangat dibutuhkan dengan upaya utama mendeteksi fraud, dan masyarakat sudah mulai merasakan pentingnya penerapan akuntansi forensik demi kelangsungan dan pengembangan ekonomi negara Indonesia.

Adapun saran dari penelitian ini yaitu peneliti selanjutnya untuk mendapatkan hasil yang lebih baik, disarankan menggunakan kuesioner, wawancara, dan survey untuk data yang lebih nyata. Penelitian ini hanya terbatas berdasarkan hasil penelitian yang sudah ada sebelumnya. Peneliti selanjutnya juga dapat menambahkan indikator fraud yang lainya.

\section{DAFTAR PUSTAKA}

Afiyanti, Y. (2008). Validitas dan Reliabilitas dalam Penelitian Kualitatif. JKI: Jurnal Keperawatan Indonesia, 12(2), 137-141.

Anggraini, D., Triharyati, E., \& Novita, H. A. (2019). Akuntansi Forensik dan Audit Investigatif dalam Pengungkapan Fraud. Journal of Economic, Bussines and Accounting (COSTING), 2(2), 372-380. https://doi.org/10.31539/costing.v2i2.708 
Anti-Corruption Clearing House. (2019). Tindak Pidana Korupsi Berdasarkan Perkara. Acch.Kpk.Go.Id. https://www.kpk.go.id/id/statistik/penindakan/tpk-berdasarkanperkara

Ardiansyah, A., Purnamasari, P., \& Gunawan, H. (2016). Penerapan Akuntansi Forensik dan Audit Investigasi terhadap Pendeteksian Fraud Asset Misappropriation ( Studi Kasus pada Badan Pengawasan Keuangan dan Pembangunan Pusat ). 695-701.

Artantri, L. P. R. M., Handajani, L., \& Pituringsih, E. (2016). Peran E-Procurement Terhadap Pencegahan Fraud Pada Pengadaan Barang/Jasa Pemerintah Daerah Di Pulau Lombok. NeO Bis, 10(1), 16-32.

Claudia, G. (2018). Akuntansi Forensik Untuk Bedah Kasus Korupsi. Jemap, 1(1), 95. https://doi.org/10.24167/jemap.v1i1.1586

Fauzan, I. A., Purnamasari, P., \& Gunawan, H. (2014). Pengaruh Akuntansi Forensik dan Audit Investigasi terhadap Pengungkapan Fraud. Penelitian Sivitas Akademika Unisba (Sosial Dan Humaniora), 2(2), 456-465.

Jenitra, I. (2018). Akuntansi Forensik Sebagai Alat untuk Mendeteksi dan Mencegah Kecurangan Pada Sektor Publik. Majalah Ilmiah Solusi, 16(1), 1689-1699.

Larasati, Y. S., Sadeli, D., \& Surtikanti. (2017). Analisis Faktor-Faktor Yang Berpengaruh Terhadap Pencegahan Fraud di Dalam Proses Pengadaan Barang dan Jasa. Jurnal Ilmiah Akuntansi Fakultas Ekonomi (JIAFE), 3, 43-60.

Modul Pelatihan Pengadaan Barang/Jasa Pemerintah., (2010).

Lidyah, R. (2016). Korupsi Dan Akuntansi Forensik. I-Finance: A Research Journal on Islamic Finance, 2(2), 72-91.

Okoye, E. I., \& Gbegi, D. O. (2013). Forensic Accounting: A Tool for Fraud Detection and Prevention in the Public Sector (A Study of Selected Ministries in Kogi State). International Journal of Academic Research in Business and Social Sciences, 3(3), 2222-6990.

Peraturan Presiden Republik Indonesia Nomor 16 Tahun 2018 tentang Pengadaan Barang/Jasa Pemerintah, Pub. L. No. Nomor 16, 1 (2018).

Pomolongan, N. (2020, August 26). KPK Sebut 70 Persen Kasus Korupsi Terkait Pengadaan Barang dan Jasa. Kompas. Com. https://nasional.kompas.com/read/2020/08/26/14404821/kpk-sebut-70-persen-kasuskorupsi-terkait-pengadaan-barang-dan-jasa

Putri, D. M. (2017). Analisis Implementasi Probity Audit Dalam Pencegahan dan Pendeteksian Fraud Pengadaan Barang dan Jasa di Universitas Gadjah Mada. ABIS : Accounting and Business Information Systems Journal, 5(3).

Ramadhan, M. S., \& Arifin, J. (2019). Efektivitas Probity Audit Dalam Mencegah Kecurangan Pengadaan Barang Dan Jasa. Jurnal Akuntansi Multiparadigma, 10(3), 550-568. https://doi.org/10.21776/ub.jamal.2019.10.3.32

Rizki, B. F., Purnamasari, P., \& Oktaroza, M. L. (2017). Pengaruh Akuntansi Forensik dan Audit Investigasi terhadap. Prosiding Akuntansi, 4(42), 513-524.

Sayyid, A. (2014). Pemeriksaan Fraud Dalam Akuntansi Forensik Dan Audit Investigatif. 
Al-Banjari: Jurnal Ilmiah Ilmu-Ilmu Keislaman, 13(2), 137-162. https://doi.org/10.18592/al-banjari.v13i2.395

Shodiq, N., Carolina, A., \& Sambharakhresna, Y. (2013). Persepsi Auditor Terhadap Penerapan Audit Forensik Dalam Mendeteksi Kecurangan Penyajian Laporan Keuangan. JAFFA, 01(2), 113-128.

Sugiyono. (2014). Metode Penelitian Kuantitatif, Kualitatif, dan Kombinasi (Mixed Methods). Alfabeta.

Tuanakotta, T. M. (2016). Akuntansi Forensik \& Audit Investigasi-Edisi 2 (2nd ed.). Salemba Empat.

Wiharti, R. R., \& Novita, N. (2020). Dampak Penerapan Akuntansi Forensik dan Audit Investigasi dalam Mendeteksi Fraud Pengadaan Barang/Jasa. Jurnal Ilmiah Akuntansi Dan Humanika, 10(2), 115. https://doi.org/10.23887/jiah.v10i2.24698

Wiralestari, W. (2016). Fraud: Akuntansi Forensik Dan Audit Investigatif. Media Riset Akuntansi, 6(1), Hal. 43-59. 